MAGDALENA CYANKIEWICZ

Muzeum Miejskie „Sztygarka”,

Dąbrowa Górnicza, Poland

m_cyankiewicz@interia.pl

DARIUSZ ROZMUS

Muzeum Miejskie „Sztygarka”,

Dąbrowa Górnicza, Poland

rozmsd@poczta.onet.pl

JOANNA TOKAJ

Muzeum Miejskie „Sztygarka”,

Dąbrowa Górnicza, Poland

j_tokaj@interia.pl
904:737.1(475)"11"

902.2(475)"2006"

069.5:902/904(475)"2006/..."

COBISS.SR-ID 219285260

Original research article

Received: December 10th 2014

Accepted: November 15th 2015

\title{
TO DISCOVER A HOARD... AND WHAT NEXT? OUR EXPERIENCES CONNECTED WITH THE STUDY, PRESENTATION AND POPULARIZATION OF THE FIND
}

\begin{abstract}
In 2006, an early medieval hoard of silver coins and cast silver was found in Dabrowa Górnicza - Łosień, near Kraków. This 12th-century find, called the "Steelworker's Hoard", discovered on the Silesian and Lesser Poland borderline, is connected with the beginnings of silver and lead metallurgy in Poland (11th - 13th centuries). This valuable find was deposited in the Municipal Museum „, Sztygar$k a$ " in Dąbrowa Górnicza. The Museum was entrusted with the challenging task of the presentation, popularization and study (including metallographic and metrological examination) of the hoard. Some interesting examples of the iconography of dinars from "Steelworker's Hoard" have oriental roots.
\end{abstract}

KEYWORDS: EARLY MIDDLE AGES, HOARD, SILVER AND LEAD METALLURGY, SILVER COINS, DENARS, ICONOGRAPHY, MUSEUM, STUDY, PRESENTATION, POPULARIZATION.

Over the last 20 years, traces of early medieval mining and metallurgy of silver and lead from the $11^{\text {th }}$ or $12^{\text {th }}$ centuries have been discovered on the borderline of such historical regions of Poland as Silesia and Lesser Poland. The centre of silver and lead production discovered in Poland and situated between Olkusz, Bytom, Siewierz and Tarnowskie Góry probably became (together with the centre in the Harz Mountains) the most important site of mining and smelting of these metals in Central Europe (Buko 2011; Foltyn 2009; Rozmus 2004 a). The production of silver and lead commenced in the above-mentioned area in the early Middle
Ages, has continued with changing intensity until now, and it particularly flourished between the $15^{\text {th }}$ and $17^{\text {th }}$ centuries.

The discovery of the $12^{\text {th }}$-century hoard of silver coins and silver nuggets in Dąbrowa Górnicza - Łosień was an important archaeological find. The hoard was discovered during standard research at a regular excavation site and can be regarded as a special bonus for archaeologists. Thursday, the 13th July 2006 was the brightest day during archaeological works lasting for several seasons at the excavation sites which showed the beginnings of the history of silver and lead metallurgy. That 


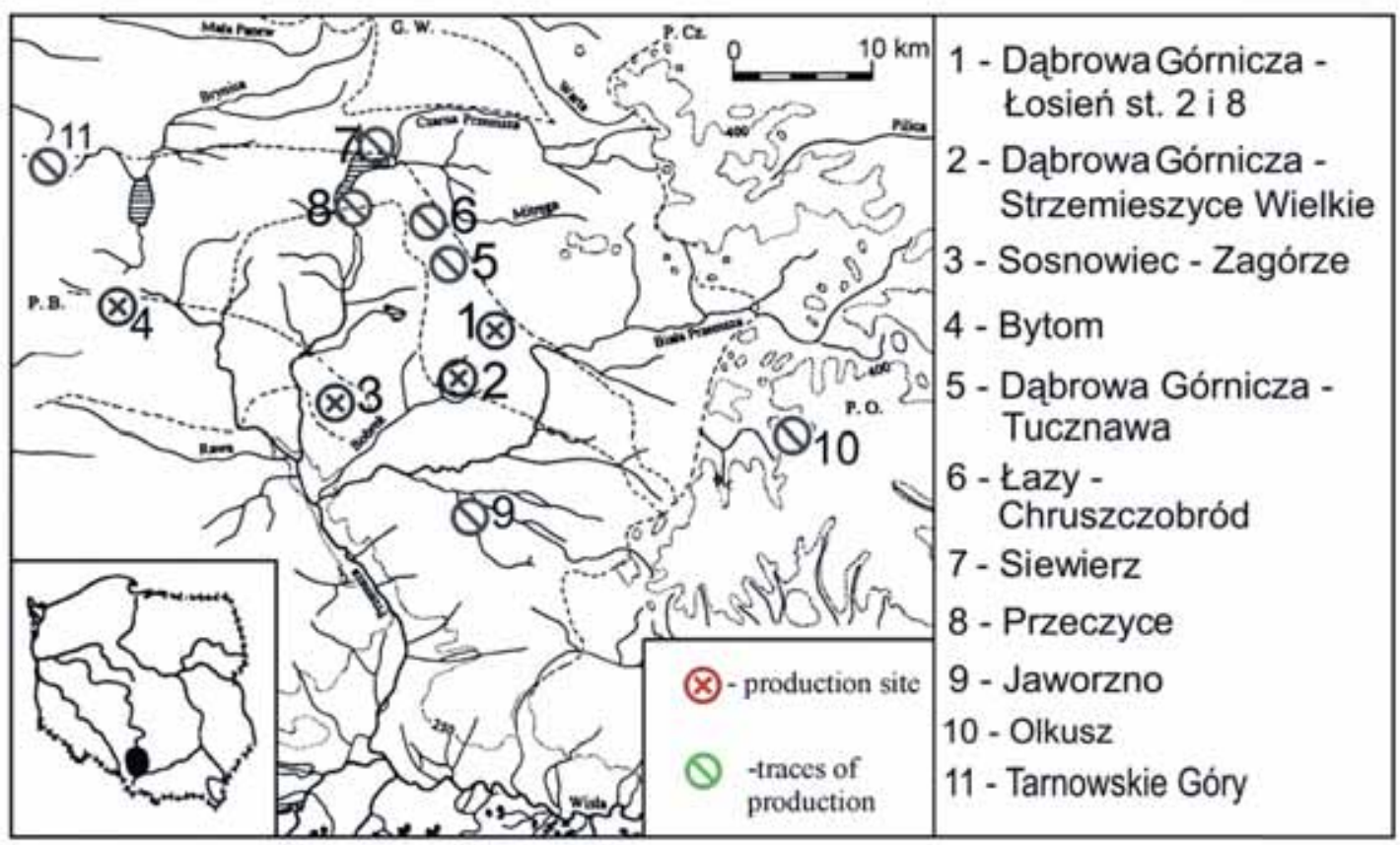

Fig. 1 The map of early medieval metallurgical sites (the borderline of Lesser Poland and Silesia) (B. Sz. Szmoniewski)

was the day when one of the biggest and most interesting hoards of the Piast Poland was discovered in Dąbrowa Górnicza - Łosień (Silesian Voivodeship). The hoard hidden in a clay pot was brought to light not by chance - as it frequently happens during construction works - but as a result of regular excavation works. What is interesting, hoards - that is precious and purposefully hidden objects, are rarely found during planned archaeological works (Krudysz et al. 2009; Tokaj and Rozmus 2012).

The hoard found in Łosień was named "Steelworker's Hoard"/ "Metalurgist Hoard". A deposit of silver denars and cast silver had been buried in the $12^{\text {th }}$ century, at the beginning of a turbulent period in the Polish history that was called "The Fragmentation", approximately between 1160 and 1165. The disappearance of the metallurgic settlement may have been caused by an armed invasion. There are several factors supporting this theory: military items found in this place, abandoned furnace with a full charge that steelworkers had not apparently had time to empty, and also most likely - the fact of hiding the treasure itself.
It is widely known that in times of unrest, war, invasion and massacre threats, people tend to hide their valuables (Tokaj and Rozmus 2012).

A major centre for glazing ceramics - a real sensation in the early medieval times in Poland - was also found in Dąbrowa Górnicza - Łosień. Numerous finds of weights also showed extensive trading relationships of miners and smelters of silver and lead (Bodnar, Rozmus, Szmoniewski 2007). The influence of ancient oriental ornamentation (for example the motifs of an eagle and a hare) and the Byzantine culture is visible in the early medieval coins from Dąbrowa Górnicza Łosień. The antique objects were influenced by the Eastern culture, including Byzantine adornment. Moreover, spindle whorls made of Volhynian schist, coming from the territory of today's Ukraine were discovered. The graves at the early medieval cemetery in Strzemieszyce Wielkie (3-4 kilometers from Łosień - currently a district of Dąbrowa Górnicza) are surrounded by stones, which shows the influence from Kievan Rus (Marciniak 1960; Rozmus, Rybak and Bodnar 2005).

After several seasons of archaeological re- 


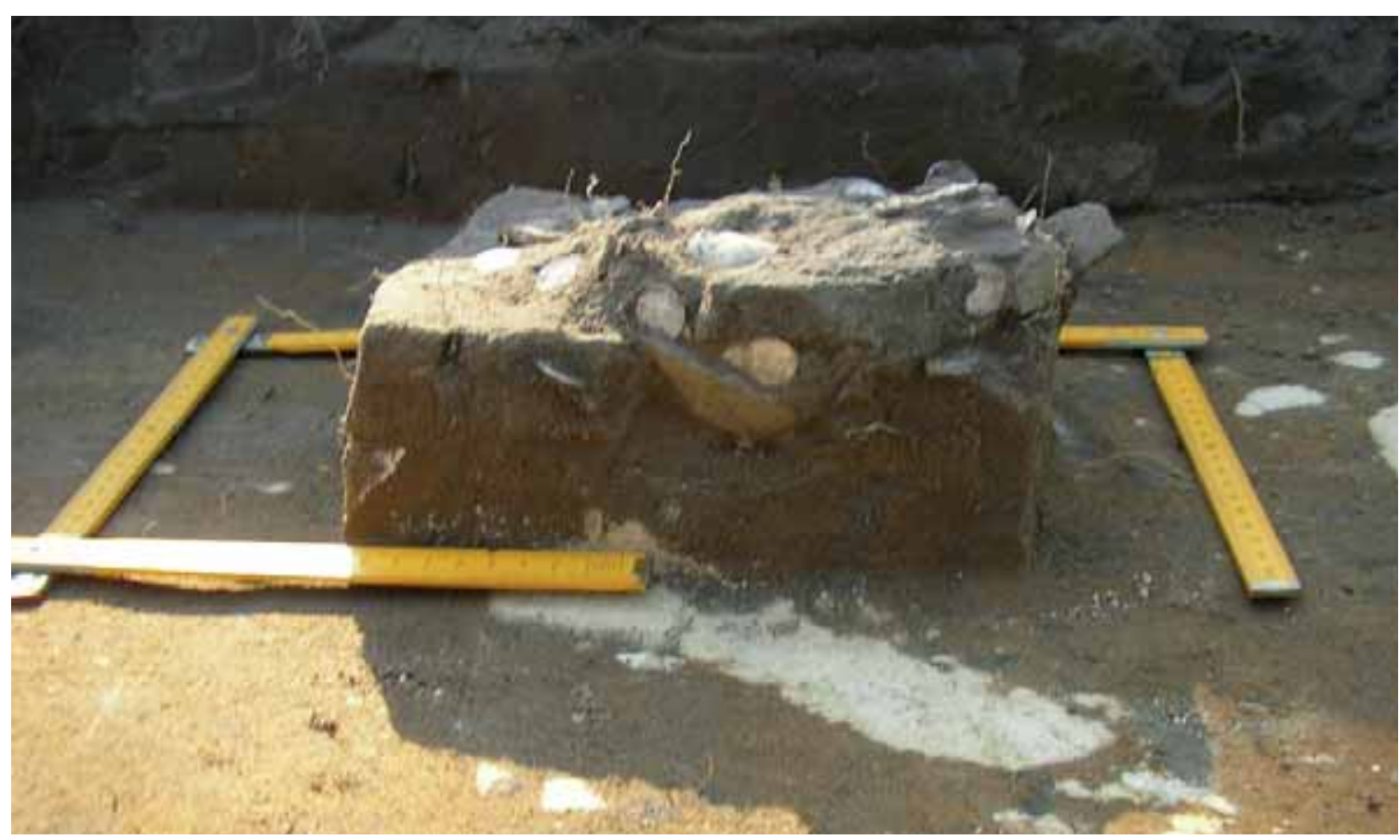

Fig. 2 The discovery of the hoard in Łosień on 13 July 2006 (a photograph by A. Wójcik)

search conducted by various research teams, we can speak about "a region of silver and lead metallurgy" existing in the early Middle Ages. Another thesis may also be formulated, stating that this metallurgy was of substantial significance for the formation and development of Poland. For many years Polish scientists, when discussing the role of economic foundations of the state of the first Piasts, considered the question of the origin of silver found in these lands as one of the most important issues. Silver was used for the production of ornaments and for minting coins. Hack silver and silver clumps (similar to those constituting the "Steelworker's Hoard") may have been used for settling trade transactions. The earliest analyses of the origin and sources of the silver material discovered in the Polish hoards from the $9^{\text {th }}$ and $10^{\text {th }}$ centuries indicated import as the exclusive source of silver. First it was assumed that the Arab coins called „dirhem" brought to Poland from the Orient had provided the material. Then another hypothesis was considered, namely that the silver may have come from the Harz Mountains (Buko 2011; Rozmus 2004 a, 2009, 2012 b).
At present, it is assumed that starting from the second half of the $11^{\text {th }}$ century, the silver came from the Western part of the Kraków region, precisely from the basins of the Przemsza and the Brynica rivers, where the traces of silver and lead extraction and smelting were discovered (Rozmus 2012b).

The discovery of the "Steelworker's Hoard", was also a challenge for the Municipal Museum „Sztygarka” in Dąbrowa Górnicza, where this valuable find was deposited. The Museum first had to fulfill specific conditions related to storing and exhibiting of such an archaeological object. For this purpose, a special display cabinet was purchased and a security alarm was installed and connected to the municipal police station. Next steps included the conservation and study of the hoard (with respect to metrology, iconography and particularly metallography). The Archaeological Division and the Marketing Division of the Museum are both responsible for the challenging task of popularization of this find. It is worth mentioning that Dąbrowa Górnicza and the surrounding region are typically industrial and are more often associated with the $19^{\text {th }}$ and $20^{\text {th }}$-century coal 


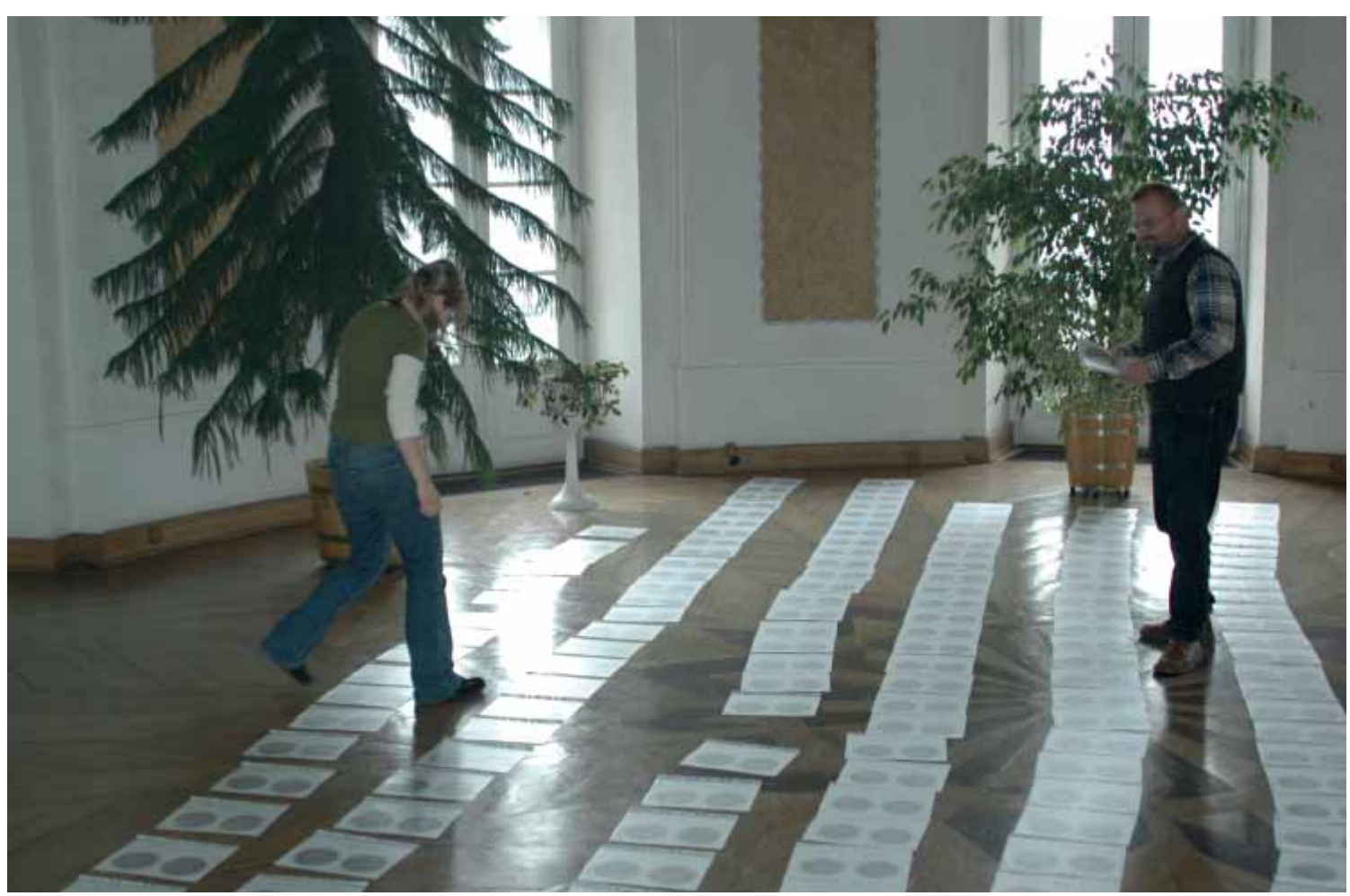

Fig. 3 The research of the hoard conducted by the authors of the forthcoming "Steelworker's Hoard" monograph (in the photograph: Joanna Tokaj and Dr Dariusz Rozmus; a photograph by B. Sz. Szmoniewski)

mining and steel industry rather than with a strong centre of silver and lead metallurgy (Tokaj, Cyankiewicz and Garbacz-Klempka 2012; Garbacz - Klempka, Rozmus 2015).

We are actively engaged in conducting the research of the "Steelworker's Hoard" and we undertake numerous activities aiming at the dissemination of the find. Exhibitions and lectures, among others, well serve this purpose. We systematically present the results of archaeological research in scientific and non-scientific publications and organize presentations and exhibitions. One of the most interesting issues presented by us is medieval minting, including Roman minting art - unique in Europe. The Museum in Dąbrowa Górnicza arranged a permanent exhibition with the reconstruction of a minting workshop and prepared a photographic exhibition that visited several cultural institutions. The initial processes, such as cutting out blanks from flattened silver bars, were reconstructed in the form of a fresco. The minting stand - a wooden base where reconstruct- ed dies for striking coins were placed - constitutes an interactive part. It was frequently used when presentations showing how coins had been struck were organized both in the Museum and during outdoor events (Cyankiewicz and Tokaj 2011; Rozmus and Tokaj 2010; Tokaj and Rozmus 2012).

The permanent exhibition shows particularly interesting examples of medieval coins. They depict knights, sovereigns or saints, sometimes showing them in a static, majestic pose, but there are expressive fighting scenes as well. We can also admire a wide range of depictions involving animals, however not always real. And thus warriors bravely fight beasts - lions and dragons, and predatory eagles attack defenceless hares (Rozmus 2012 a; Tokaj 2012; Rozmus and Tokaj 2012).

Not only did medieval coins have esthetic values, but they also served other purposes. Sovereigns frequently used them to convey certain messages to their subjects or political rivals. The mysterious language of medieval numismatics is 


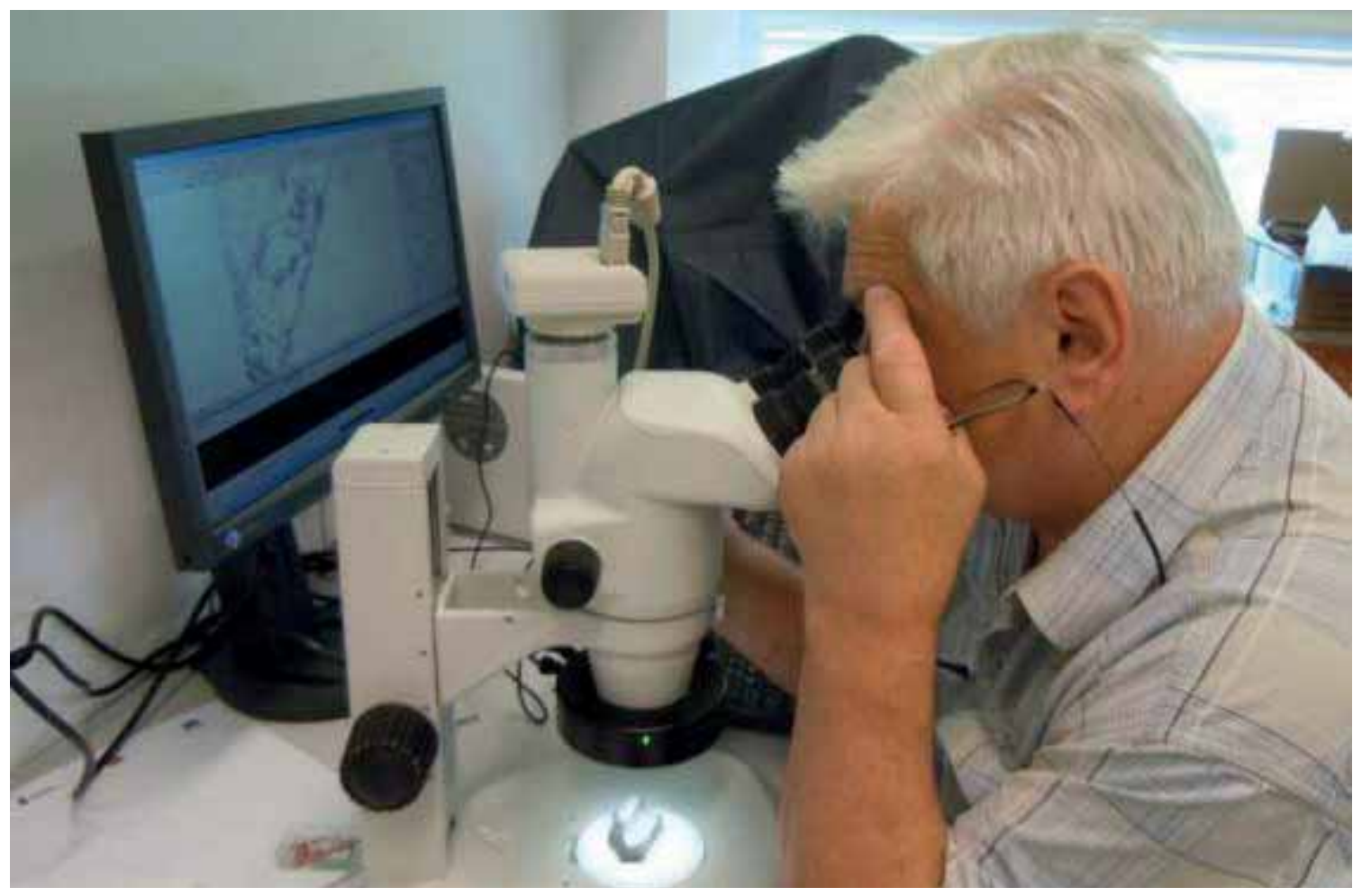

Fig. 4 a-b Metallographic examination of the coins at the University of Science and Technology in Kraków. In the photograf S. Rzadkosz (a photograph by P. Jurecki)

extremely difficult to understand today (Suchodolski 2012).

The authors of this article wish to point out the best examples of early medieval iconography, particularly those unknown outside Poland. The $12^{\text {th }}$-century coins issued by Ladislaus II the Exile (1138-1146) and Boleslaus the Curly (died 1173) constitute an example of Roman micro-engraving art which is unique on a European scale. The iconography of coins shows Western European, Czech and Byzantine - oriental influence. Some of the engravings - such as the denar of two brothers and the denar of three brothers do not have any analogies in the iconography of medieval coins in Europe. They show two or three prince's celebrants sitting at a table in a majestic scene in which they are raising up a prince's orb (the denar of two brothers) (Tokaj and Rozmus 2012).

The subject of our studies are scenes with oriental roots that were changed by the Byzantine civilisation. We are currently working on the symbolism of coins depicting hunting scenes of Byzantine - oriental origin and on the symbolism of majestic effigies. We have so far worked out the iconography of depictions of St. Adalbert. An important motif is an effigy resembling an icon which shows the head of St. Adalbert, a bishop and a martyr from a noble Czech family of Prince Slavník. The bishop was martyred in his efforts to convert the Baltic Prussians. St. Adalbert is not only the patron of Poland, but also of the Czech Republic and Hungary (Suchodolski 2000, 2005; Labuda 2000; Rozmus and Tokaj 2010).

Apart from the research of the iconography of denars, we are conducting analyses leading to a full monograph of the find. First, each coin and lump was photographed, weighed and measured, and then cards with magnified denars were prepared on the basis of the photographic documentation, which significantly facilitated the work of the researchers. Next, the coins within their types were divided into variants - that is denars which had been coined with the use of a specific coin die. Thus the so called "connection chains" were created, which help to determine which coins were coined earlier than others. Lumps of silver and 


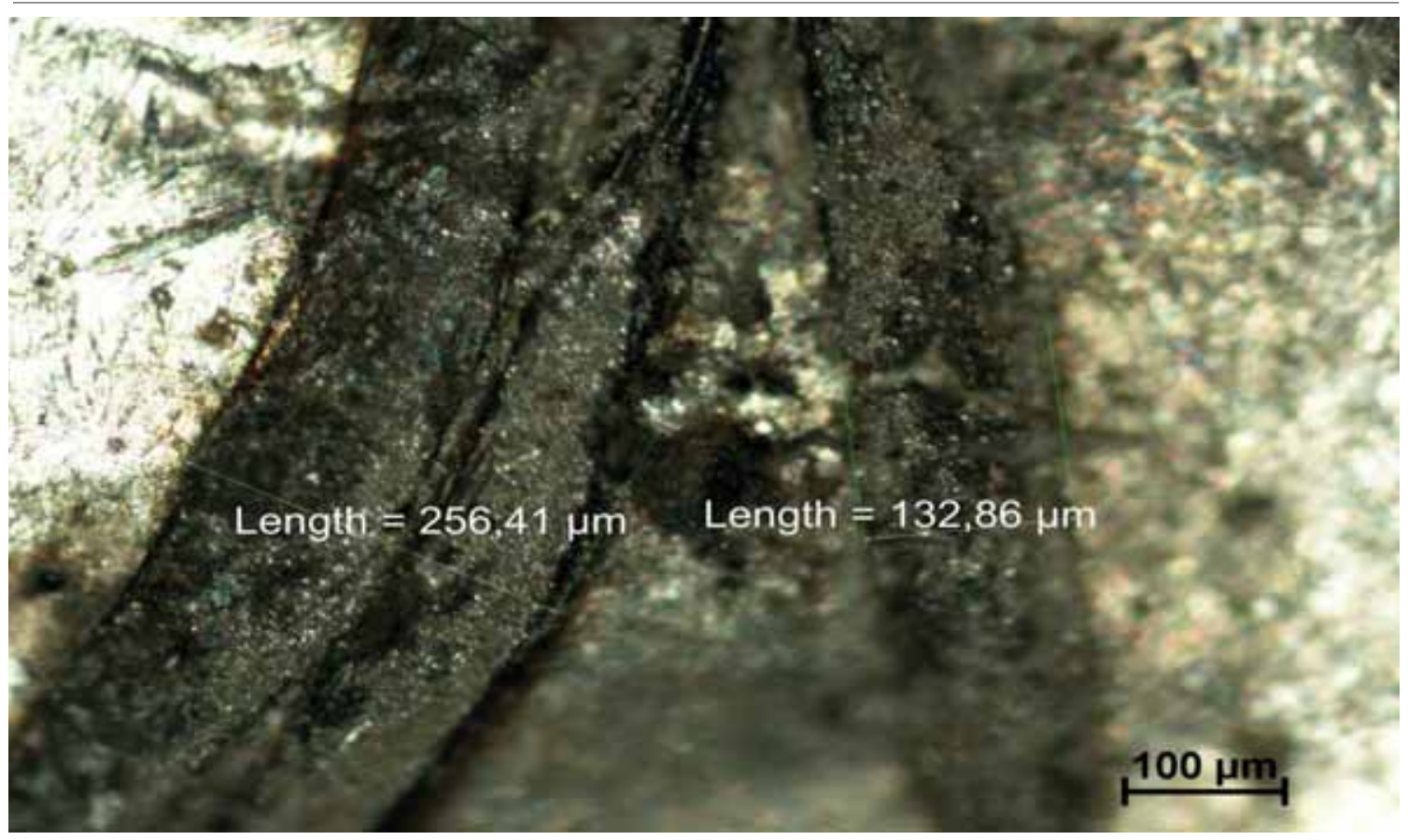

Fig. 4 a-b Metallographic examination of the coins at the University of Science and Technology in Kraków (a photograph byP. Jurecki)

chosen coins were also examined metallographically. The examination was conducted in cooperation with the University of Science and Technology in Kraków and the Museum of Archaeology and Ethnography in Łódź. The results of the examination were compared with the examination results of lumps from other medieval hoards (Garbacz-Klempka, Rozmus and Tokaj, 2013; Tokaj, Cyankiewicz and Garbacz-Klempka 2012).

All the above activities were undertaken within the frames of the project carried out since 2011, called "Industriae Theatrum ex Silesia". The project involved people of all age groups (so called lifelong learning). One of the events that deserves particular mention accompanied a series of lectures directed to students of the University of the Third Age. During one of the lectures, employees of the Faculty of Foundry Engineering from the University of Science and Technology in Kraków presented a living history show of smelting with the use of medieval methods.

Referring to the use of natural resources, and in particular lead, in the Middle Ages, we decided to reconstruct the processes of melting and smelting alloys composed mainly of lead. The basis for the experiment were archeological finds from Lesser Poland and Silesia, as well as written sources from the $12^{\text {th }}$ century (Teofil Prezbiter 1998). The conclusions of the observations and research found more practical application as they were transferred from a laboratory to be used in the reconstruction works. Designs of the furnace for melting metals, crucibles and appropriate alloys were prepared. Project participants took part in the final stages of the process, which gave them the opportunity to gain practical knowledge about the medieval craft of melting and smelting metals. The furnace smoked, the alloy in the crucible changed to liquid, previously prepared casting moulds were filled and then opened after cooling down. In this way, within the frames of the project, medieval ornaments were made, using patterns known from archeological research. Thus, this scientific and research work took on a practical dimension and contributed to the dissemination of knowledge concerning metal ores, medieval technological processes and finished products made of metals and their alloys. Therefore, one of the most essential aims of the project was achieved: the industry of the Middle Ages was shown in a 


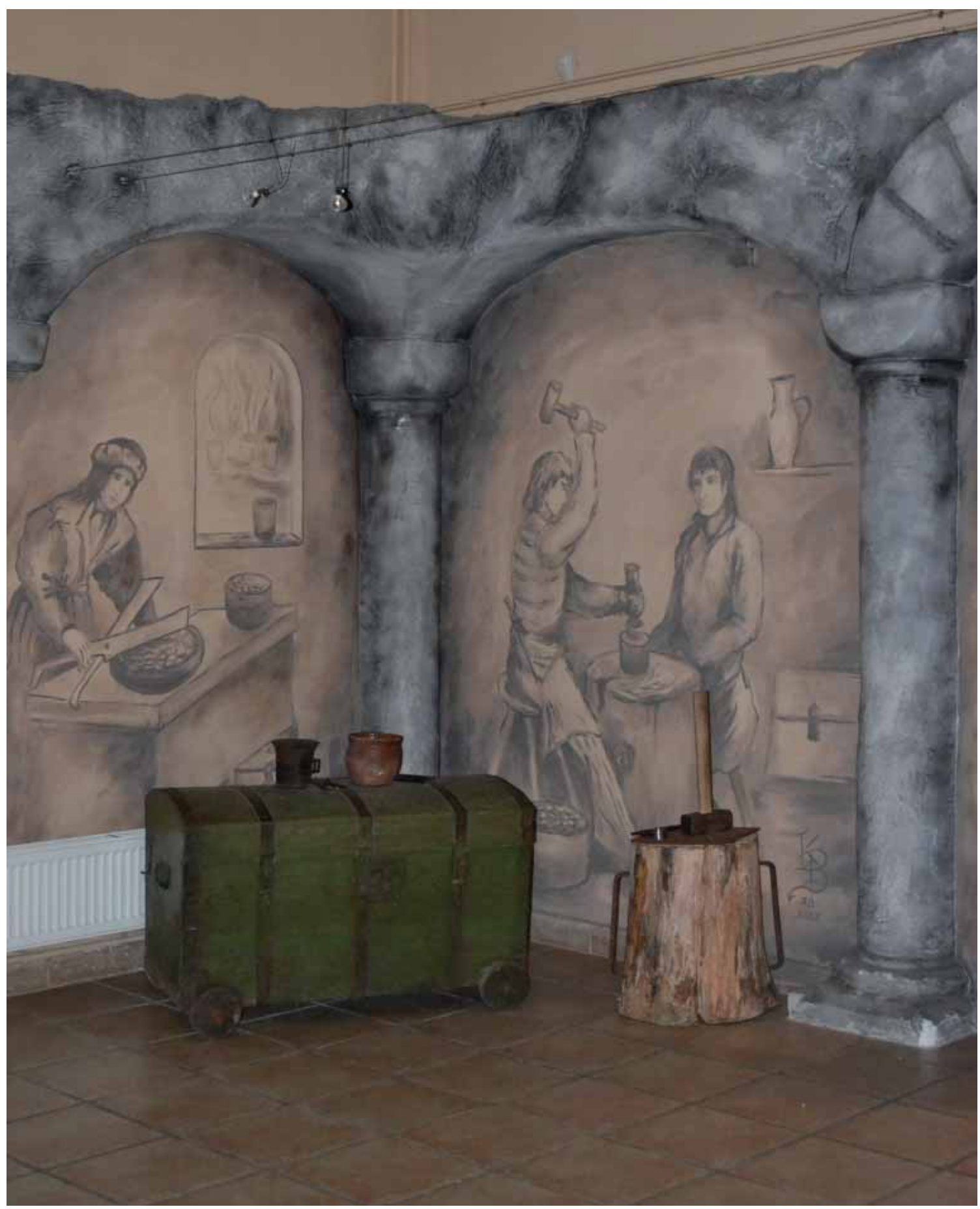

Fig. 5 The reconstruction of a medieval mint in the Municipal Museum „Sztygarka” in Dąbrowa Górnicza (a photo by J. Tokaj)

modern city and with active participation of its inhabitants, using the findings presented in scientific and research works (Tokaj, Cyankiewicz and Garbacz-Klempka 2012).

The interest of the researchers in the process of minting coins in the Middle Ages resulted in the reconstruction of the above mentioned minting workshop.

Coins were struck at mints, which were manufactories that employed several dozen people. Mints were administered by magister monetae who managed a team of employees, including 


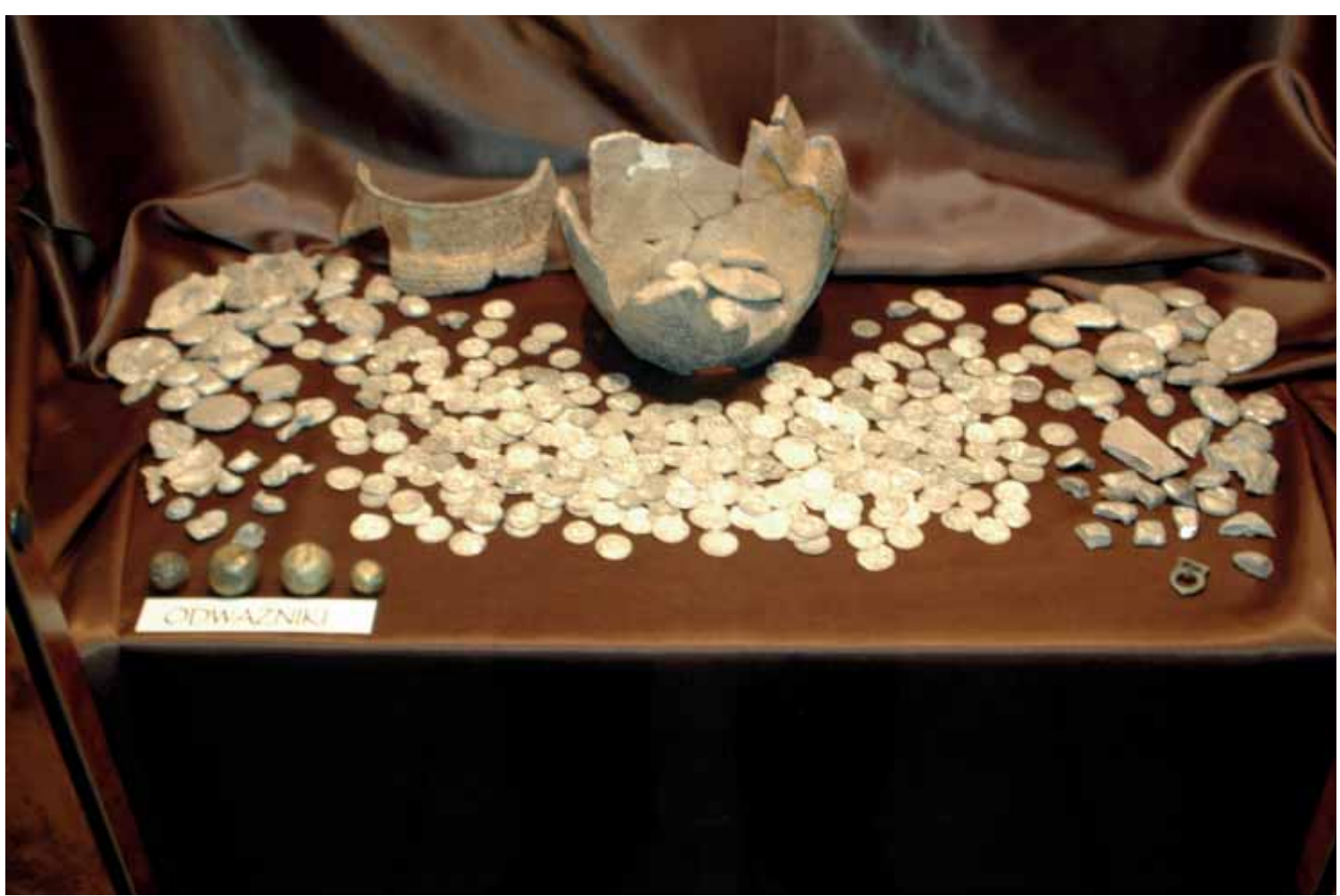

Fig. 6 A fragment of a permanent exhibition of the "Steelworker's Hoard” in the Municipal Museum „Sztygarka” in Dąbrowa Górnicza (a photograph by K. Borda)

mint masters, apprentices, workers and die engravers. In all likelihood, the administrators also held public functions, most likely they were responsible for all financial resources of the mint.

In order to strike coins, dies had to be made first. They were most likely of the shape of a cylinder or a truncated cone. The face was that part of a die where the image to be placed on the silver planchet was engraved. Carving the design for a coin was an extremely laborious and precise work, therefore it also required high qualifications. The engraving was made with a graver and a pair of compasses.

When striking a coin, the planchet was situated between the dies, and then the upper die was hit with a hammer. The average life of a pair of dies varied - they could crack after striking several dozen or even several thousand coins. Polish mints most likely employed local prince's goldsmiths to produce dies (Suchodolski 1973; Kiersnowski 1964).

Since the discovery of the hoard, that is for the last 8 years, the results of the archaeological re- search have been systematically presented in both scientific publications and publications for the general public, as well as in the local press and even tabloids. Several specialist lectures and outdoor and mass activities have been organized (an event at a shopping mall, a theme event, "The Autumn of the Middle Ages"). Some of the lectures and lessons have been directed to both students of the University for the Third Age and the University for Children.

In 2012, the Museum, together with the Society of Friends of Dąbrowa Górnicza and the University of Science and Technology in Kraków, carried out a project "Valuable, priceless, extracted from the earth..." and issued a bilingual brochure „Steelworker's Hoard” from Dąbrowa Górnicza - Łosien and a bookmark with the pictures of the most valuable coins from this Hoard. The project that included both lectures and presentations of coin minting succeeded in popularizing interdisciplinary issues from the history of art, medieval science, numismatics and archaeology to the general public (Tokaj and Rozmus 2012). 

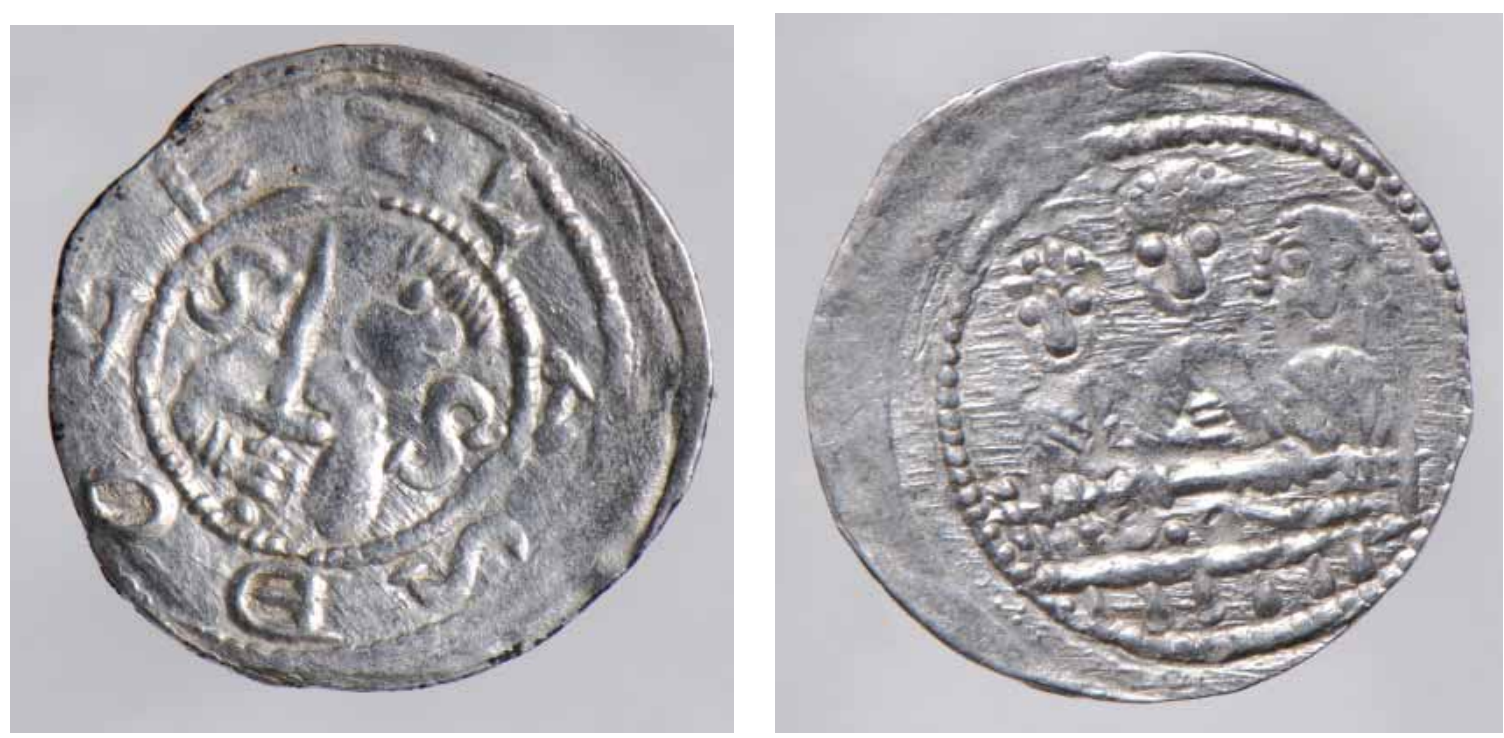

Fig. 7 a-b Type 4 denar of Boleslaus IV the Curly: the obverse and the reverse (the „Steelworker's Hoard”, a photograph by J. Popielarz)
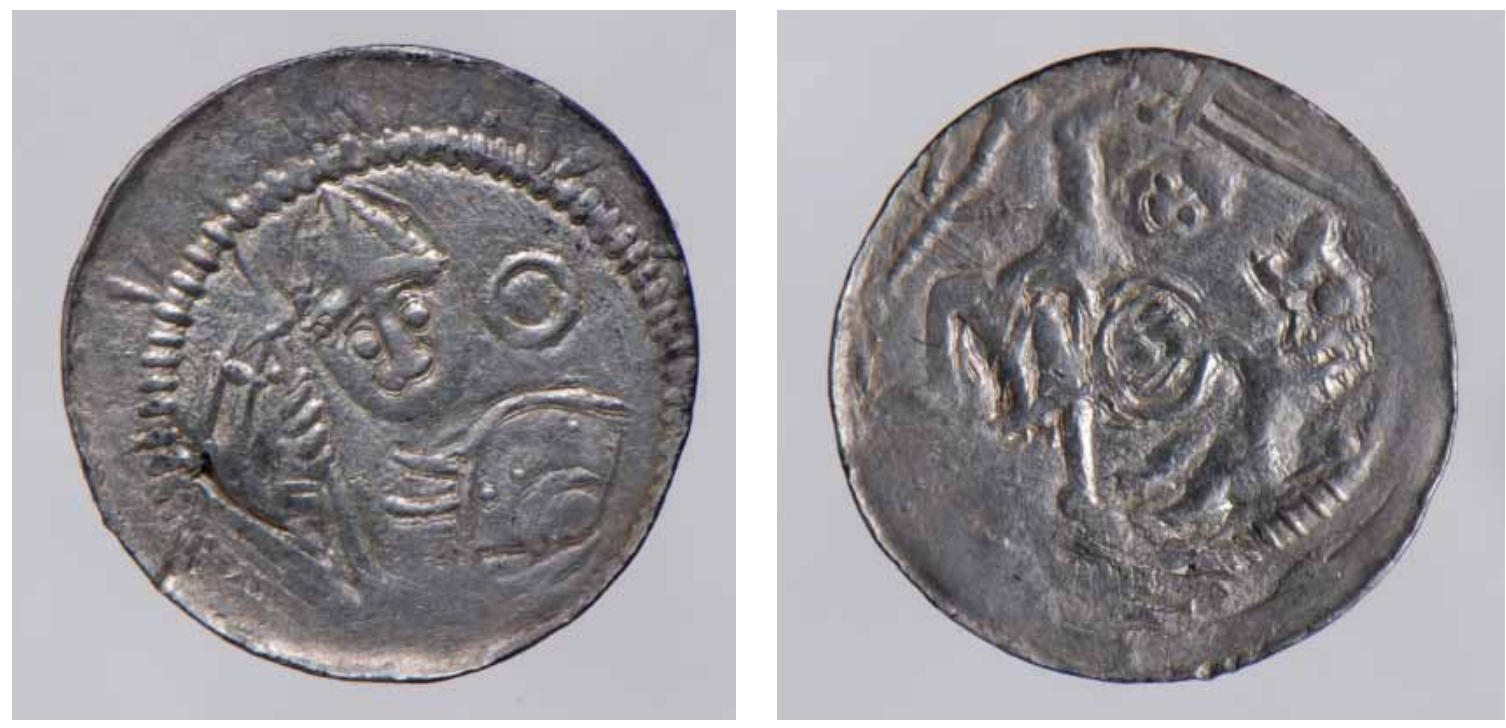

Fig. 8 a-b Type 3 denar of Ladislaus II the Exile: the obverse and the reverse (the,,Steelworker's Hoard”, a photograph by J. Popielarz)

To sum up our experiences over the last few years, we can say that thanks to the discovery of the hoard and a wide range of activities popularizing the discovery, the Museum in Dąbrowa Górnicza - which is not a museum with a long tradition - gained an interesting opportunity of promotion. In 2014 was published the monograph of the Metallurgist Hoard (Rozmus, Suchodolski, Tokaj 2014).

\section{BIBLIOGRAPHY}

Bodnar, R., Rozmus, D. and Szmoniewski, B. Sz. 2007

Wczesnośredniowieczne odważniki i ciężarki ołowiane z Dąbrowy Górniczej - Lośnia = Early Medieval Commercial Weights and Lead Weights from Dąrowa Górnicza-Łosień. Dąbrowa Górnicza and Kraków, Księgarnia Akademicka. 
Buko, A. 2011

Archeologia Polski wczesnośredniowiecznej. Odkrycia-hipotezy-interpretacje. Warszawa, Wydawnictwo TRIO.

\section{Chowaniec, R. 2010}

Dziedzictwo archeologiczne $w$ Polsce. Formy edukacji i popularyzacji. Warszawa, Instytut Archeologii, Uniwersytet Warszawski.

\section{Chowaniec, R. and Więckowski W. 2012}

Archaeological Heritage: Methods of Education and Popularization, (BAR International Series 2443), Oxford, Archaeopress Publishers of British Archaeological Reports.

Cyankiewicz, M. and Tokaj, J. (eds.) 2011

Idustriae Theatrum ex Silesia czyli archeologia przemystowa wieków średnich dla każdego $=$ Industial Archeology of the Middle Ages for Everyone, Dąbrowa Górnicza, Towarzystwo Przyjaciół Dąbrowy Górniczej and Muzeum Miejskie „Sztygarka".

\section{Foltyn, E. M. 2009}

Podstawy źródłowe do badań nad gospodarką społeczności wczesnośredniowiecznych w dorzeczu Przemszy, in: Gospodarka nad Przemsza i Brynica od pradziejów do poczatków XX wieku $w$ świetle badań interdyscyplinarnych, Rozmus, D. and Witkowski, S. (eds.), Dąbrowa Górnicza, Olkusz and Sosnowiec, Muzeum Miejskie „Sztygarka" etc., 13-67.

Garbacz - Klempka, A., Rozmus, D. and Tokaj, J. 2013

"Skarb hutnika" w świetle badań metaloznawczych, in: Argenti fossores et alii. Znaczenie gospodarcze wschodnich części Górnego Śląska i zachodnich krańców Małopolski w późnej fazie wczesnego średniowiecza (X-XII wiek), P. Boroń (ed.), Wrocław, Chronicon: 203 - 224.
Garbacz - Klempka, A., Rozmus, D., 2015

The "Metallurgist's Hoard". Silver and Lead Smelting in the Early Medieval Poland, in: Archives of Foundty Engineering, vol. 15, Special Issue 1/2015, Katowice - Gliwice, Polish Academy of Sciences: $17-20$.

\section{Garbaczewski, W. 2007}

Ikonografia monet piastowskich 1173 - ok. 1280. Warszawa and Lublin, Polskie Towarzystwo Numizmatyczne.

\section{Kalicki T., Rozmus D. and Szmoniewski B. 2009}

Człowiek i środowisko na przykładzie rejonu strzemieszycko-łosieńskiego - pierwsze wyniki $=$ Man and environment on the example of the Strzemieszyce-Losień region - preliminary results, in: Srodowiskowe uwarunkowania lokalizacji osadnictwa $=$ Environmental determinants of settlement location: Środowisko, Człowiek, Cywilizacja, vol. 2, Seria wydawnicza Stowarzyszenia Archeologii Środowiskowej, L. Domańska, P. Kittel and J. Forysiak (eds.), Poznań, Bogucki Wydawnictwo Naukowe: 215-219.

\section{Karbowniczek, M. et al. 2006}

An Attempt of Reproduction of the Medieval Technology of Lead Metallurgy, in: Wczesnośredniowieczna ceramika szkliwiona z Dabrowy Góniczej- Łośnia. „Skarb hutnika”, = Frühmittelalterliche glasierte Keramik aus Dąbrowa Górnicza-Losien': „Der Schatz des Mettalschmelt$z e s$, D. Rozmus and B. Sz. Szmoniewski (eds.), Kraków and Dąbrowa Górnicza: Księgarnia Akademicka: 36-40.

\section{Karbowniczek, M. and Suliga, I. 2005}

Próba rekonstrukcji wczesnośredniowiecznej technologii redukcji rud ołowiu na podstawie wykopalisk archeologicznych w Dąbrowie Górniczej-Lośniu, (Summary: Early Medieval lead ore reduction technology. Trial reconstruction on basis of archeological evidence from Dąbrowa 
Górnicza-Łosień, Upper Silesia) Ślaskie Sprawozdania Archeologiczne XLVII, 2005, J. M. Budurkiewicz (ed.) Wrocław: Instytut Archeologii Uniwersytetu Wrocławskiego: 135-143.

\section{Kiersnowski, R. 1964}

Wstęp do numizmatyki polskiej wieków średnich, Warszawa, Państwowe Wydawnictwo Naukowe.

\section{Kiersnowski, R. 1988}

Moneta $w$ kulturze wieków średnich, Warszawa, Państwowy Instytut Wydawniczy.

\section{Kiersnowski, R. et al. (eds) 2002}

Moneta mediaevalis. Studia numizmatyczne i historyczne ofiarowane Profesorowi Stanistawowi Suchodolskiemu w 65. rocznice urodzin, Warszawa, Instytut Archeologii i Etnologii Polskiej Akademii Nauk and „D i G”.

Kowalska, E. and Urbaniak, E. (eds.) 2010

Muzeum XXI wieku - teoria i praxis. Materiaty z sesji naukowej, organizowanej przez Muzeum Początków Państwa Polskiego i Polski Komitet Narodowy ICOM. Gniezno, 25-27 listopada 2009 roku. Księga pamiatkowa poświęcona Profesorowi Krzysztofowi Pomianowi. (Biblioteka Muzeum Początków Państwa Polskiego 4), Gniezno, Muzeum Początków Państwa Polskiego.

Krudysz, L., Rozmus, D., Suchodolski, S. and Szmoniewski, B. Sz. 2009

Znaleziska monet średniowiecznych z miejscowości Łosień (część Dąbrowy Górniczej). Wiadomości Numizmatyczne LIII/1 (187), Warszawa: Komitet Nauk Historycznych PAN and ELIPSA: 56-65.

\section{Labuda, G. 2000}

Święty Wojciech : biskup - męczennik, patron Polski, Czech i Wegier, Wrocław, Fundacja na Rzecz Nauki Polskiej.

\section{Marciniak, J. 1960}

Cmentarzysko szkieletowe z okresu wczesnośredniowiecznego w Strzemieszycach Wielkich pow. Będzin, Materiały Wczesnośredniowieczne V, 1960, Warszawa, Państwowe Muzeum Archeologiczne w Warszawie: 141-185.

\section{Rozmus, D. 2004 a}

Wczesnośredniowieczne Zagłębie Metalurgii Srebra i Ołowiu na terenie Dąbrowy Górniczej i okolic, in: Początki i rozwój miast Górnego Ślass$k a$. Studia interdyscyplinarne $=$ Počátky a rozvoj měst v Horním Slezsku : mezidisciplinární studium, M. Michnik, D. Abłamowicz and M. Furmanek (eds.), Seria Monograficzna 10, Biblioteka Katowicka 18, Gliwice: Muzeum w Gliwicach, Oddział Katowicki Stowarzyszenia Naukowego Archeologów Polskich 301-305.

Rozmus, D. (ed.) 2004 b

Archeologiczne $i$ historyczne ślady górnictwa $i$ hutnictwa na terenie Dąbrowy Górniczej i okolic, Kraków, Księgarnia Akademicka.

\section{Rozmus, D. 2009}

Próba rekonstrukcji procesu wytopu srebra i ołowiu w XI i XII w. (na przykładzie osady produkcyjnej w Dąbrowie Górniczej-Łośniu); Summary: An attempt of silver and lead smelting process reconstruction in 11th and 12th century (on the example of mining settlement in Dąbrowa Górnicza- Łosień), Wytwórczość w Polsce średniowiecznej i nowożytnej: Archeologia Historica Polona 18, 2008, J. Chudziakowa (ed.), Toruń, Wydawnictwo Naukowe Uniwersytetu Mikołaja Kopernika: 45-55.

\section{Rozmus, D. 2012 a}

„Nocny łowca" i inni... Sceny towieckie na monetach ze „Skarbu hutnika”, Dąbrowa Górnicza Kraków, Księgarnia Akademicka. 


\section{Rozmus, D. 2012 b}

Pochodzenie srebra odnajdywanego w Polsce we wczesnym średniowieczu (Sum.: The origin of silver found in the Early Middle Ages), Magazyn Numizmatyczny 38, 2012, Częstochowa: Polskie Towarzystwo Numizmatyczne, Oddział w Częstochowie: 46-75.

\section{Rozmus, M. and Rozmus, D. 2008}

Jak w praktyce edukacyjnej zastosować archeologię?, in: Regionalizm w szkolnej edukacji. Pogranicze ślasko-małopolskie (Górny Śląsk, Zagłębie Dąbrowskie, ziemia olkuska), D. Rozmus and S. Witkowski (eds.), Sosnowiec: Oficyna Wydawnicza „Humanitas” and Liceum Ogólnokształcące im. Stanisława Staszica: 19-23.

\section{Rozmus, D., Rybak, A. and Bodnar R. 2005}

Z dziejów przemystu dąbrowskiego. Archeologia. Przemyst. Katalog wystawy, Dąbrowa Górnicza and Kraków, Księgarnia Akademicka.

\section{Rozmus, D. and Suliga, I. 2012}

Piece i paleniska o przeznaczeniu hutniczym do wytopu ołowiu ze stanowiska nr 5 w Sosnowcu-Zagórzu - wstępne wyniki badań prowadzonych w latach 2009-2010, (Summary, Zusammenfassung) Śląkie Prace Prahistoryczne 7, 2012, M. Kurgan-Przybylska (ed.), Katowice, Muzeum Śląskie w Katowicach: 169-200.

\section{Rozmus, D. and Szmoniewski, B. (eds) 2006}

Wczesnośredniowieczna ceramika szkliwiona z Dąbrowy Góniczej - Łośnia. „Skarb hutnika” $=$ Frühmittelalterliche glasierte Keramik aus Dąbrowa Górnicza-Łosień: „,Der Schatz des Mettalschmeltzes, Kraków and Dąbrowa Górnicza, Księgarnia Akademicka.

\section{Rozmus, D. and Szmoniewski, B. Sz., 2008}

Wczesnośredniowieczne ołowiarstwo na terenie Słowiańszczyzny a relacja Ibrahima Ibn Jakuba (Summary: Early Medival Lead processing in the Slavic Territories and Account of Ibrahim Ibn
Yaqub) in: Ibrahim Ibn Jakub i Tadeusz Kowalski w sześćdziesiąta rocznice edycji. Materiaty z konferencji naukowej. Kraków, 10 maja 2006 r. = Tadeusz Kowalski and His Edition of Ibrahim Ibn Jakub sixty years later, A. Zaborowski (ed.), Kraków, Księgarnia Akademicka: 83-89.

Rozmus, D. and Tokaj, J. 2009

Wstępne wyniki badań nad „Skarbem Hutnika” - problematyka srebrnych placków, in: Gospodarka nad Przemsza i Brynica od pradziejów do poczatków XX wieku w świetle badań interdyscyplinarnych, Rozmus, D. and Witkowski, S. (eds.), Dąbrowa Górnicza, Olkusz and Sosnowiec, Muzeum Miejskie „Sztygarka” etc.: 103-115.

Rozmus, D. and Tokaj, J. 2010

Oblicza świętego Wojciecha na monetach Bolesława Kędzierzawego, Dąbrowa Górnicza and Kraków, Księgarnia Akademicka.

\section{Rozmus, D. and Tokaj, J. 2011}

Badania archeologiczne w rejonie Strzemieszyc Wielkich i Strzemieszyc Małych, in: Strzemieszyce Mate. Srebrna Perła Dąbrowy Górniczej, J. Krajniewski (ed.), Dąbrowa Górnicza: Muzeum Miejskie „Sztygarka”: 23-31.

Rozmus, D. and Tokaj, J. 2012

Denary napisowe Bolesława Kędzierzawego ze "Skarbu hutnika" z Dąbrowy Górniczej Łośnia, Magazyn Numizmatyczny 37, 2012, Częstochowa: Polskie Towarzystwo Numizmatyczne, Oddział w Częstochowie: 115-122.

\section{Rozmus, D. and Witkowski, S. (eds.) 2009}

Gospodarka nad Przemsza i Brynica od pradziejów do początków XX wieku w świetle badań interdyscyplinarnych, Dąbrowa Górnicza, Olkusz and Sosnowiec, Muzeum Miejskie „Sztygarka” etc.

Rozmus, D., Suchodolski, S., Tokaj, J. 2014

Wczesnośredniowieczny "skarb hutnika" z Dąbrowy Górniczej - Łośnia. Monografia. Część 
1 = Early Medieval "Metallurfist Hoard" from Dąbrowa Górnicza - Losień. A Monograph. Part 1, Dąbrowa Górnicza, Muzeum Miejskie "Sztygarka".

Sperka, J. and Witkowski, S. (eds.) 2005

Osadnictwo nad Przemsza i Brynica w średniowieczu, Sosnowiec and Cieszyn: Liceum Ogólnokształcące im. Stanisława Staszica w Sosnowcu and PTH Oddział Cieszyn.

\section{Suchodolski, S. 1973}

Mennictwo polskie $w$ XI i XII wieku, Wrocław etc.: Zakład Narodowy im. Ossolińskich - Wydawnictwo Polskiej Akademii Nauk.

\section{Suchodolski, S. 2000}

Kult św. Wacława i św. Wojciecha przez pryzmat polskich monet z wczesnego średniowiecza, in: Kościót, kultura, społeczeństwo. Studia z dziejów średniowiecza i czasów nowożytnych, S. Bylina (ed.), Warszawa, Instytut Historii PAN - Semper: 87-102.

\section{Suchodolski, S. 2005}

Kult svatého Václava a svatého Vojtěcha prizmatem raně středověkých polských mincí. Numismatický sborník 20 : 2005, Praha, Centrum medievistických studií Univerzity Karlovy: 2942.

\section{Suchodolski, S. 2012}

Numizmatyka średniowieczna. Moneta źródtem archeologicznym, historycznym i ikonograficznym, Warszawa, TRIO.

\section{Teofil Prezbiter, transl. S. Kobielus, 1998}

Diversarum Artium Schedula - Średniowieczny zbiór przepisów o sztukach rozmaitych, Kraków, Tyniec Wydawnictwo Benedyktynów.

\section{Tokaj, J. 2012}

„Władca w majestacie" na przykładzie monet z tzw. „Skarbu hutnika” z Dąbrowy Górniczej
- Łośnia - wybrane przykłady, Magazyn Numizmatyczny 38: 2012, Częstochowa: Polskie Towarzystwo Numizmatyczne, Oddział w Częstochowie: 104-110.

Tokaj, J., Cyankiewicz, M. and Garbacz Klempka, A. 2012

Industriae Theatrum Ex Silesia: Showing the functioning of a medieval industry in a contemporary industrial conurbation, in: Archaeological Heritage: Methods of Education and Popularization, R. Chowaniec and Więckowski W. (eds), (BAR International Series 2443), Oxford, Archaeopress Publishers of British Archaeological Reports: $167-174$.

Tokaj, J. and Rozmus, D. 2012

„Skarb hutnika” z Dąbrowy Górniczej - Łośnia = 'Steelworker's Hoard' from Dabrowa Górnicza - Łosień; (Industiae Theatrum ex Silesia, 3, 2012, M. Cyankiewicz and J. Tokaj (eds), Dąbrowa Górnicza, Towarzystwo Przyjaciół Dąbrowy Górniczej and Muzeum Miejskie „Sztygarka”.

\section{Wojtala, I. (transl.) 2012 a}

„Skarb hutnika” z Dąbrowy Górniczej - Łośnia = 'Steelworker's Hoard' from Dabrowa Górnicza - Łosień, Dąbrowa Górnicza: Towarzystwo Przyjaciół Dąbrowy Górniczej and Muzeum Miejskie „Sztygarka”.

\section{Wojtala, I. (transl.) 2012 b}

Industriae Theatrum Ex Silesia: Showing the functioning of a medieval industry in a contemporary industrial conurbation, in: Archaeological Heritage: Methods of Education and Popularization, R. Chowaniec and Więckowski W. (eds), (BAR International Series 2443), Oxford, Archaeopress Publishers of British Archaeological Reports: $167-174$.

Wrzesiński, J. and Wyrwa, A. M. (eds.) 2010

Przeszłość dla przyszłości - problemy edukacji muzealnej. Materiaty Konferencji z okazji Jubi- 
leuszu 40-lecia Muzeum Pierwszych Piastów na Lednicy, Lednica 11-13 września 2009 roku, (Biblioteka Studiów Lednickich, 18, A/2), Lednica, Muzeum Pierwszych Piastów na Lednicy (Musaeum Primorum Principum ex Stripe Piastea in Lednica).

\section{REZIME OTKRITI BLAGO...I ŠTA ONDA? NAŠA ISKUSTVA SA OBRADOM, PREZENTACIJOM I POPULAR- IZACIJOM NAZALIŠTA}

KLJUČNE REČI: RANI SREDNJI VEK, OSTAVA, METALURGIJASREBRAIOLOVA,SREBRNINOVAC, IKONOGRAFIJA, MUZEJ, OBRADA, PREZENTACIJA, POPULARIZACIJA.

Godine 2006, tokom arheoloških istraživanja, otkriveno je blago iz XII veka od preko hiljadu srebrnih novčića, zajedno sa oko 2 kilograma kovanog srebra. Nalaz potiče iz grada Dombrova Gurniča (Dąbrowa Górnicza), četvrti Uošenj (Łosień), koji se nalazi u blizini Krakova, gde je bila kneževska kovnica novca.

Otkriće blaga bilo je neka vrsta kulminacije istraživačkog rada sprovedenog na granici provincija Malopoljske i Šleske. Ranije na ovom području nekoliko poslednjih istraživačkih sezona rezultiralo je otkrićem ranih srednjovekovnih nalazišta, povezanih sa počecima metalurgije srebra i olova na području Poljske (od Xi do XIII veka).

Blago, koje se zove "Topioničarevo blago", takođe je izazov za Gradski muzej Štigarka (Sztygarka) u gradu Dombrova Gurniča, gde je čuvano kao jedno od najvrednijih otkrića na ovome području. Muzej je prvo morao da ispuni određene uslove (uključujući bezbednosne mere), u vezi sa mogućnostima čuvanja i izlaganja ove vrste arheoloških nalaza. Naredni koraci, koji su uključili održavanje i obradu blaga, rezultiraće objavljivanjem monografije. Odeljenje za arheologiju i odeljenje za marketing Gradskog muzeja nastojali su da popularizuju ovo arheološko otkriće. Od otkrića blaga sistematski se predstavljaju rezultati arheoloških istraživanja grupama posetilaca različite starosne dobi.

Najzanimljiviji obrađivani primeri ikonografije ranih srednjovekovnih novčica predstavljaju različite prizore orijentalnog porekla (npr. prizori lova, slike veličanstvenog Sv. Vojtjeha Adalberta, zaštitnika Poljske). Pored izučavanja ikonografije novčića, takođe se vrše istraživanja iz oblasti metalurgije i metrologije. 